\title{
Penggunaan Sistem Penjaring Informasi Hoaks dalam Menerapkan Pendidikan Anti-Hoaks bagi Guru di Masa Pandemi COVID-19
}

\author{
Rahmi Ramadhani $^{*}$, Abdul Meizar ${ }^{2}$, Dwi Ardiyanti ${ }^{3}$ \\ ${ }^{1}$ Teknik Informatika, Universitas Potensi Utama, Jalan K.L. Yos Sudarso KM. 6,4 No. 3-A Tanjung Mulia, \\ Medan, Indonesia, 20241 \\ ${ }^{2}$ Sistem Informasi, Universitas Potensi Utama, Jalan K.L. Yos Sudarso KM. 6,4 No. 3-A Tanjung Mulia, \\ Medan, Indonesia, 20241 \\ ${ }^{3}$ Hubungan Internasional, Universitas Potensi Utama, Jalan K.L. Yos Sudarso KM. 6,4 No. 3-A Tanjung \\ Mulia, Medan, Indonesia, 20241 \\ *Email Korespondensi: rahmiramadhani3@gmail.com
}

\begin{abstract}
Abstrak
Permasalahan yang dialami sekolah mitra diperoleh melalui observasi dan wawancara, diantaranya guru mitra mengalami kesulitan dalam mencari sumber referensi pembelajaran yang valid dan terpercaya untuk digunakan dalam materi pembelajaran selama proses pembelajaran daring. Guru mitra juga sering memperoleh tautan yang mengandung informasi yang belum dapat dipercaya dan dikhawatirkan masuk dalam kategori informasi hoaks. Berdasarkan permasalahan tersebut, Tim PKM melaksanakan kegiatan program kemitraan masyarakat dengan tujuan untuk memberikan pelatihan dan pendampingan penerapan sistem penjaring informasi hoaks sebagai upaya untuk menerapkan pendidikan anti-hoaks bagi guru-guru selama proses pembelajaran jarak jauh berbasis daring di masa pandemi COVID-19. Jumlah peserta kegiatan PKM ini adalah sebanyak 28 orang guru.Target luaran kegiatan PKM ini adalah (1) terdapat peningkatan dan pemahaman para guru terkait informasi hoaks yang bererdar di media sosial maupun media berita online lainnya; (2) terdapat peningkatan keterampilan guru dalam menggunakan aplikasi sistem penjaring informasi hoaks yang telah dirancang oleh Tim PKM; (3) peningkatan keterampilan guru dalam melakukan proses penjaringan informasi hoaks menggunakan aplikasi dan melakukan proses pengecekan terkait informasi yang diperoleh melalui penelusuran online; serta (4) peningkatan motivasi dan semangat guru dalam menerapkan Pendidikan anti-hoaks dalam proses pembelajaran jarak jauh selama masa pandemi COVID-19. Hasil yang diperoleh dari kegiatan PKM ini adalah (1) para guru mampu melakukan pemilihan informasi yang akan digunakan dalam proses pembelajaran jarak jauh; (2) para guru mampu menggunakan aplikasi sistem penjaring informasi hoaks; dan (3) para guru mampu menerapkan Pendidikan anti-hoaks dalam proses pembelajaran baik selama masa pandemic COVID19 maupun masa New Normal.
\end{abstract}

Kata kunci: Informasi hoaks; sistem penjaring informasi hoaks; website; pendidikan anti hoaks

\begin{abstract}
The problems experienced by partner schools are obtained through observation and interviews, among them partner teachers having difficulty in finding valid and reliable learning reference sources to use in learning materials during the online learning process. Partner teachers also often obtain links that contain untrustworthy information and are feared to be in the category of Hoax information. Based on these problems, the PKM Team conducted community partnership program activities with the aim of providing training and assistance in the implementation of Hoax information-learning system as an effort to implement anti-Hoax education for teachers during the online-based distance learning process during the COVID-19 pandemic. The number of participants in this PKM activity is as many as 28 teachers. The external target of this PKM activity is (1) there is an increase and understanding of the teachers regarding the information of the hoax that are related to social media and other online news media; (2) There is an increase in teacher's skill in using the Hoax information scorer system application that has been planned by team PKM; (3) Improvement of teachers ' skills in the process of going through the Hoax information using the application and checking the information obtained through online search; and (4) Increased teacher motivation and spirit in implementing anti-hoax education in distance learning process during pandemic COVID-19 period. The results obtained from this
\end{abstract}


PKM activity are (1) the teachers are able to conduct the selection of information to be used in the distance learning process; (2) Teachers are able to use the Hoax information goal system application; and (3) teachers are able to implement anti-hoax education in the process of learning both during the COVID-19 pandemic period and New Normal period.

Keywords: hoax information; hoax information scorer system; website; anti-hoax education

Format Sitasi: Ramadhani, R., Meizar, A., Ardiyanti, D. (2020). Penggunaan Sistem Penjaring Informasi Hoaks dalam Menerapkan Pendidikan Anti-Hoaks bagi Guru di Masa Pandemi COVID-19. Jurnal Solma, 09(2), 278-289. Doi: http://dx.doi.org/10.22236/solma.v9i2.5423

Diterima: 21 Agustus 2020 | Revisi: 05 September 2020 | Dipublikasikan: 30 Oktober 2020

(C) 2020 Oleh authors. Lisensi Jurnal Solma, LPPM-Uhamka, Jakarta. Artikel ini bersifat open access yang didistribusikan di bawah syarat dan ketentuan Creative Commons Attribution (CC BY) license. (http://creativecommons.org/licenses/by/4.0/).

\section{PENDAHULUAN}

Berkembangnya Teknologi, Informasi dan Komputer (TIK) memberikan banyak perubahan yang signifikan di berbagai sektor, yang salah satunya adalah dunia pendidikan. Integrasi TIK dalam dunia pendidikan memberikan ruang baik bagi guru maupun siswa dalam melaksanakan proses pembelajaran yang berbasis teknologi dan internet. Guru tidak lagi hanya menggunakan buku cetak sebagai referensi dan rujukan dalam pemberian materi ajar, namun telah menggunakan sistem pencari informasi berbasis teknologi, seperti Google untuk memperkaya referensi dan rujukan. Begitu pula yang dilakukan oleh siswa yang tidak lagi hanya terfokus mencari informasi melalui buku teks sekolah saja, melainkan juga dapat mencari informasi tambahan melalui mesin pencari Google. Kurikulum pembelajaran juga memberikan akses untuk menerapkan teknologi dalam proses pembelajaran, seperti yang tercantum dalam penjabaran Kurikulum 2013 dimana penggunaan teknologi tidak hanya dijadikan sebagai media saja, melainkan juga dapat digunakan sebagai bahan serta bagian dari proses pembelajaran (Kementerian Pendidikan dan Kebudayaan, 2013). Langkah ini juga didukung oleh ketersediaan berbagai informasi yang berada di jaringan internet untuk dapat digunakan sebagai informasi dan rujukan tambahan dalam pelaksanaan pembelajaran. Tersedianya berbagai website pendidikan, blog pembelajaran membantu para guru maupun siswa dalam memperoleh berbagai informasi tambahan yang membantu meningkatkan kualitas pembelajaran (Sartono, 2016; Sulasmianti, 2019).

Akses informasi yang semakin meluas memberikan kesempatan pada siswa untuk memperoleh informasi dimana saja dan kapan saja, tanpa lagi dibatas oleh ruangan kelas. Hingga pada akhirnya keberadaan TIK dalam dunia pendidikan semakin sangat dibutuhkan ketika proses pembelajaran dipaksa bertransformasi dalam bentuk pembelajaran jarak jauh (PJJ) akibat dari pandemi COVID-19 sejak bulan Februari 2020. Penerapan pembelajaran jarak jauh (PJJ) sebagai bagian dari upaya pencegahan penyebaran COVID-19 dilakukan dengan mengutamakan teknologi sebagai bagian dari proses pembelajaran (Pakpahan \& Fitriani, 2020). Pembelajaran jarak jauh sendiri dapat diartikan sebagai pembelajaran dengan menggunakan media yang memungkinkan terjadi interaksi antara guru maupun siswa tanpa melakukan kegiatan tatap muka secara langsung. Artinya, pembelajaran jarak jauh dapat 
dilakukan oleh siswa maupun guru walaupun tidak berada pada lokasi yang sama (Prawiyogi et al., 2020).

Pembelajaran jarak jauh memanfaatkan internet sebagai media utama dalam terlaksananya proses pembelajaran, yang artinya lembaga pendidikan, seperti sekolah harus sudah memiliki fasilitas internet ketika melaksanakan program pembelajaran jarak jauh. Berbagai platform pembelajaran berbasis daring (dalam jaringan) digunakan oleh guru, seperti Google Classroom, pengembangan sistem e-learning yang dilakukan pihak sekolah dengan menggunakan Learning Management System, seperti Schoology, Moodle, penggunaan aplikasi video conference seperti Google Meet dan Zoom Meeting, hingga adanya partisipasi dari pihak pengembang swasta, seperti Genius maupun Ruang Guru memberikan bantuan tersendiri dalam terlaksananya proses pembelajaran berbasis daring (online learning). Akibat dari hal tersebut, penggunaan internet semakin meluas (Latip, 2020). Akses informasi yang meluas memberikan dampak positif hingga dampak negatif baik bagi guru maupun siswa. Salah satu dampak positif dalam penggunaan teknologi pada proses pembelajaran adalah meningkatnya keterampilan menggunakan aplikasi teknologi, baik bagi siswa maupun guru. Namun, dibalik itu, terdapat pula dampak negatif yang salah satunya adalah tidak terkontrolnya akses informasi yang dilakukan baik siswa maupun guru, hingga tidak jarang menggunakan informasi yang terindikasi hoaks sebagai informasi rujukan dalam proses pembelajaran.

Kurangnya kontrol dalam penggunaan informasi melalui internet ini pada akhirnya menciptakan kondisi tertentu dimana siswa maupun guru tanpa sadar menggunakan hingga membagikan informasi yang belum valid kebenarannya. Kemudahan akses berbagi serta semakin banyaknya media sosial yang dapat digunakan baik oleh guru maupun siswa juga memberikan kesempatan tersendiri bagi informasi yang tidak kredibel untuk diakses dan diteruskan secara meluas. Penelitian yang dilakukan oleh Pertiwi (2019) memperoleh hasil bahwa media sosial facebook merupakan media sosial yang paling banyak digunakan oleh masyarakat. Sebanyak 150 juta pengguna media sosial di Indonesia adalah pengguna aktif media sosial facebook. Hal ini disebabkan media sosial facebook memiliki banyak fitur yang memudahkan informasi tersebar dengan massif (Nugraha, 2019). Kemudahan tersebut pada akhirnya menjadi jebakan bagi siswa maupun guru, dimana tidak sadar bahwa menjadi bagian dari penyebar informasi hoaks. Masalah di atas, menjadi semakin pelik tatkala para guru menjadikan media sosial sebagai salah satu media pembelajaran selama pembelajaran jarak jauh di masa pandemi COVID-19 dilaksanakan (Juditha, 2018; Sadikin \& Hamidah, 2020).

Guru sekolah mitra mengalami permasalahan terkait pengumpulan referensi-referensi materi ajar yang akan digunakan dalam mengembangkan bahan ajar. Selama proses pembelajaran daring yang terjadi sebagai akibat dari pandemi COVID-19, para guru di sekolah mitra mempersiapkan bahan ajar yang akan dikirmkan melalui platform pembelajaran daring kepada masing-masing siswa. Guru-guru di sekolah mitra tidak mengalami kendala yang berarti dalam mengakses informasi melalui internet, hal ini dikarenakan pihak sekolah mitra sudah sejak dulu menyediakan akses jaringan internet gratis untuk digunakan baik oleh guru maupun siswa di sekolah. Pembelajaran melalui jejaring internet juga sudah sejak dulu dilaksanakan oleh sekolah mitra. Namun, masalah muncul 
ketika pelaksanaan pembelajaran daring dilakukan. Guru-guru terkendala ketika mencari informasi untuk dijadikan referensi dalam bahan ajar. Terkadang, guru-guru memperoleh informasi yang masih diragukan kebenarannya, selain itu juga tidak jarang guru-guru memperoleh link informasi yang tidak sesuai antara judul dan isi informasi yang disajikan.

Untuk itu, diperlukan suatu kegiatan yang memberikan edukasi kepada guru maupun siswa terkait bagaimana menggunakan sumber informasi kredibel yang berasal dari media internet sebagai bagian referensi tambahan dalam proses pembelajaran. Target kegiatan ini adalah untuk memberikan pengetahuan dan pemahaman para guru terkait seperti apa informasi hoaks tersebut, lalu bagaimana menyikapi informasi hoaks yang ditemukan melalui media sosial maupun kanal berita online hingga bagaimana menjaring informasiinformasi yang masih diragukan kebenarannya. Kegiatan ini pada akhirnya akan bermuara kepada penerapan pendidikan anti-hoaks bagi siswa. Pendidikan anti-hoaks sangat penting untuk diterapkan agar siswa memiliki kemampuan dasar untuk bersikap kritis, analitik dan cerdas dalam menyampaikan informasi, khususnya melalui media sosial.

\section{MASALAH}

Fakta di lapangan menunjukkan bahwa pencarian informasi melalui media internet tidak memiliki kontrol yang jelas. Para guru maupun siswa mengalami kesulitan dalam memilah informasi yang ditemukan melalui media internet, baik yang berasal dari media sosial maupun yang berasal dari kanal berita online. Hal ini sesuai dengan observasi dan wawancara yang dilakukan kepada Ibu Kepala Sekolah Mitra, yakni Ibu Nurhaida O. Siregar, M.Pd bahwa guru masih kesulitan dalam menentukan apakah informasi yang diperoleh merupakan informasi yang valid atau tidak. Guru juga tidak memiliki keterampilan dalam melakukan pengecekan yang lebih mendalam terkait sumber informasi yang digunakan. Hal ini semakin dipersulit sejak pembelajaran jarak jauh diberlakukan oleh Kemendikbud. Merujuk dari hal tersebut, maka diperlukan sosialisasi terkait informasi hoaks dan bagaimana ciri-ciri informasi yang terindikasi sebagai informasi hoaks. Selain itu, diperlukan juga pelatihan dan pendampingan penggunaan alat maupun aplikasi tambahan yang dapat digunakan sebagai media pengecekan sumber informasi berdasarkan indicatorindikator informasi hoaks.

Tantangan pada kegiatan pengabdian masyarakat ini adalah alat atau media seperti apa yang dapat digunakan oleh guru hingga nantinya oleh siswa dalam memilah informasi yang dijadikan referensi dalam penyampaian materi ajar. Selain itu, bagaimana mengembangkan alat atau media pengecek informasi yang mudah untuk digunakan oleh para guru. Untuk menjawab tantangan tersebut, maka tim PKM melakukan pengembangan aplikasi sistem penjaring informasi hoaks berbasis website. Diharapkan dengan adanya aplikasi sistem penjaring informasi hoaks berbasis website dapat membantu para guru maupun siswa nantinya dalam melakukan pengecekan sumber informasi sebelum digunakan dalam proses pembelajaran, baik pembelajaran daring (online learning) selama pandemi COVID-19 maupun nantinya ketika pembelajaran tatap muka (face-to-face learning) sudah dilaksanakan kembali di masa New Normal. 


\section{METODE PELAKSANAAN}

Metode yang digunakan dalam kegiatan ini adalah:

1. Metode ceramah atau presentasi terkait sosialiasi dalam pengenalan informasi hoaks, contoh-contoh informasi hoaks yang beredar di media internet (baik media sosial, maupun pada kanal berita online), ciri-ciri informasi hoaks serta cara memilah informasi yang diperoleh melalui media internet. Metode ini dilaksanakan dengan dua fase, yakni fase tatap muka (face-to-face training) dan fase daring (online training). Hal ini dikarenakan adanya larangan melakukan kegiatan atau pertemuan dalam jangka waktu yang lama. Sehingga, agar kegiatan PKM tetap terlaksana dengan baik, maka dilakukan dalam dua tahap, yakni fase tatap muka dan fase daring.

2. Metode demonstrasi, yakni menunjukkan cara menggunakan aplikasi sistem penjaring informasi hoaks berbasis website kepada para guru sekolah mitra.

3. Metode praktek, yakni untuk melihat sudah sejauh apa pemahaman dan pengetahuan yang diperoleh para guru terkait informasi hoaks dan melihat apakah para guru sudah mampu menggunakan aplikasi system penjaring informasi hoaks atau belum.

Pelaksanaan program kemitraan masyarakat (PKM) ini juga melibatkan mahasiswa sebagai anggota lapangan. Mahasiswa turut andil dalam membantu tim PKM baik Ketika pelaksanaan kegiatan di lapangan, maupun melalui Zoom Meeting. Mahasiswa juga membantu dalam merancang flyer kegiatan ketika dilaksanakan dalam format online workshop berjenis web seminar (Webinar) serta membantu dalam memberikan angket kegiatan sebelum dan setelah kegiatan dilaksanakan. Pelaksanaan kegiatan PKM dilakukan dengan langkah-langkah sebagai berikut:

Tahap pertama adalah tahap persiapan yang meliputi kegiatan observasi dan wawancara serta survei ke lokasi kegiatan PKM. Kegiatan ini dilakukan untuk melihat gambaran lokasi kegiatan serta melihat kesiapan sekolah mitra terkait keikusertaan pada kegiatan PKM ini. Tahap ini juga dilakukan untuk mendata berapa jumlah guru yang akan mengikuti kegiatan ini dan seperti apa teknis kegiatan yang akan dilaksanakan.

Tahap kedua adalah tahap sosialisasi dan pelatihan. Pada tahap ini, Tim PKM menggunakan metode blended-training (pelatihan gabungan antara pelatihan tatap muka dan pelatihan daring). Hal ini dilakukan karena mengantisipasi penyebaran COVID-19 dan terkait tidak diperbolehkannya melakukan kegiatan dalam kurun waktu yang lama. Berikut jadwal kegiatan sosialisasi dan pelatihan yang dilakukan oleh Tim PKM:

Tabel 1. Daftar Kegiatan PKM

\begin{tabular}{|c|c|c|c|}
\hline Materi & Pemateri & Fase Kegiatan & Waktu \\
\hline Pembelajaran Daring & Rahmi & Tatap Muka & 11 Juli 2020 Pukul \\
\hline $\begin{array}{l}\text { Selama Pandemi } \\
\text { COVID-19 }\end{array}$ & $\begin{array}{l}\text { Ramadhani, } \\
\text { S.Pd.I., M.Pd }\end{array}$ & (Sekolah Mitra) & 09.00-11.00 WIB \\
\hline Aplikasi Pembelajaran & Abdul Meizar, & Tatap Muka & 13 Juli 2020 Pukul \\
\hline $\begin{array}{l}\text { Daring Selama } \\
\text { Pandemi COVID-19 }\end{array}$ & S.Kom., M.Kom & (Sekolah Mitra) & 09.00-11.00 WIB \\
\hline Bahan Ajar Digital & $\begin{array}{l}\text { Rahmi } \\
\text { Ramadhani, } \\
\text { S.Pd.I., M.Pd }\end{array}$ & $\begin{array}{l}\text { Tatap Muka } \\
\text { (Sekolah Mitra) }\end{array}$ & $\begin{array}{l}\text { 14 Juli 2020 Pukul } \\
\text { 09.00-11.00 WIB }\end{array}$ \\
\hline
\end{tabular}




\begin{tabular}{|c|c|c|c|}
\hline $\begin{array}{l}\text { Pengenalan Dasar } \\
\text { Informasi Hoaks, } \\
\text { Konten Informasi } \\
\text { Hoaks dan Media } \\
\text { Sosial }\end{array}$ & $\begin{array}{l}\text { Dwi Ardiyanti, } \\
\text { S.S., M.A }\end{array}$ & $\begin{array}{l}\text { Zoom Meeting } \\
\text { (Webinar PKM } \\
\text { Series 1) }\end{array}$ & $\begin{array}{l}18 \text { Juli } 2020 \text { Pukul } \\
14.00-15.00 \text { WIB }\end{array}$ \\
\hline Ciri-Ciri Informasi & Dr. (Cand) Ade & Zoom Meeting & 18 Juli 2020 Pukul \\
\hline Hoaks & $\begin{array}{l}\text { Ma'ruf } \\
\text { Wirasenjaya, } \\
\text { S.IP., M.A }\end{array}$ & $\begin{array}{l}\text { (Webinar PKM } \\
\text { Series 1) }\end{array}$ & 15.00-16.00 WIB \\
\hline $\begin{array}{l}\text { Peran Teknologi } \\
\text { dalam Pencegahan } \\
\text { Informasi Hoaks }\end{array}$ & $\begin{array}{l}\text { Muhardi Saputra, } \\
\text { S.Kom., M.Kom }\end{array}$ & $\begin{array}{l}\text { Zoom Meeting } \\
\text { (Webinar PKM } \\
\text { Series 2) }\end{array}$ & $\begin{array}{l}25 \text { Juli } 2020 \text { Pukul } \\
\text { 14.00-15.00 WIB }\end{array}$ \\
\hline Penggunaan Aplikasi & Abdul Meizar & Zoom Meeting & 25 Juli 2020 Pukul \\
\hline $\begin{array}{l}\text { Sistem Penjaring } \\
\text { Informasi Hoaks } \\
\text { Berbasis Website }\end{array}$ & S.Kom., M.Kom & $\begin{array}{l}\text { (Webinar PKM } \\
\text { Series 2) }\end{array}$ & 15.00-16.00 WIB \\
\hline
\end{tabular}

Tahap ketiga adalah tahap pendampingan dan penggunaan aplikasi sistem penjaring informasi hoaks berbasis website. Tahap ini dilaksanakan melalui fase daring menggunakan fasilitas WhatsApp Group. Pendampingan dilakukan dengan memberikan kembali video penggunaan aplikasi sistem penjaring informasi hoaks berbasis website dan melakukan diskusi serta tanya jawab.

Tahap keempat adalah tahap evaluasi hasil penggunaan sistem penjaring informasi hoaks berbasis website yang digunakan dalam menerapkan pendidikan anti-hoaks bagi guru dan siswa sekolah mitra. Tahap evaluasi dilakukan dengan memberikan angket kuisioner melalui google form baik di WhatsApp Group maupun ketika pelaksanaan kegiatan online. Pada tahapan ini, Tim Hibah PKM Universitas Potensi Utama juga akan memberikan saran dan pendapat kepada sekolah mitra dalam pelaksanaan pembelajaran daring selama masa pandemik COVID-19.

Tahap kelima adalah tahap analisis hasil evaluasi penggunaan sistem penjaring informasi hoaks berbasis website yang diperoleh melalui angket (google form) sebelum dan setelah dilakukannya kegiatan sosialisasi, pelatihan dan pendampingan. Data dianalisis menggunakan statistik deskriptif untuk mengetahui peningkatan pemahaman serta keterampilan para guru dalam persentase setelah menggunakan sistem penjaring informasi hoaks dalam menerapkan pendidikan anti-hoaks pada proses pembelajaran. Hasil perhitungan data angket juga disajikan dalam bentuk grafik lingkaran untuk melihat persentase atas hasil angket yang telah direspon oleh guru.

\section{HASIL DAN PEMBAHASAN}

Berdasarkan hasil kegiatan program kemitraan masyarakat (PKM) yang telah dilakukan oleh Tim PKM di sekolah mitra, diperoleh beberapa temuan diantaranya:

1. Para guru masih memberikan beragam respon terkait informasi hoaks dan media sosial yang sering digunakan khususnya dalam proses pembelajaran. Berdasarkan hasil pertanyaan tersebut, diketahui bahwa para guru dominan mengartikan informasi hoaks sebagai informasi bohong, serta konten informasi yang paling sering disusupi informasi 
hoaks adalah konten informasi politik. Selain itu, lebih dari setengah jumlah peserta PKM yakni guru sepakat bahwa aplikasi pesan singkat WhatsApp dan media sosial facebook adalah aplikasi yang paling sering digunakan. Temuan ini diperoleh ketika kegiatan sosialisasi fase daring dilakukan. Pemateri yang merupakan pelaksana PKM memberikan beberapa pertanyaan seputar seperti apa gambaran informasi hoaks yang selama ini diketahui oleh para guru melalui bantuan aplikasi www.mentimeter.com.

2. Temuan lain yang diperoleh dari kegiatan ini adalah para guru masih kesulitan dalam menggunakan teknologi sebagai bagian dari proses pembelajaran berbasis daring (online learning). Hasil temuan ini diperoleh ketika kegiatan sosialisasi fase tatap muka (face-toface training) dilakukan di sekolah mitra. Pada kegiatan tersebut para guru selama ini hanya menggunakan WhatsApp Group sebagai media pembelajaran selama masa pandemic COVID-19. Para guru belum memiliki pengetahuan dan keterampilan dalam menggunakan platform pembelajaran daring lainnya. Hal ini disebabkan kurangnya kemampuan para guru dalam menggunakan teknologi pada proses pembelajaran, serta perubahan teknis pembelajaran yang secara tiba-tiba dilakukan, sehingga para guru tidak memiliki kesempatan dalam mempersiapkan media serta bahan ajar untuk digunakan pada pembelajaran daring. Hal ini sesuai dengan hasil penelitian yang diperoleh Soewarno, Hasmiana \& Faiza (2016) bahwa sebanyak 53,33\% guru tidak memiliki latar belakang pendidikan yang terampil dalam menggunakan TIK. Senada dengan hasil penelitian tersebut, Nasution (2010) menambahkan bahwa kurangnya keterampilan TIK pada guru disebabkan guru tidak memiliki keterampilan teknik untuk mengendalikan TIK tersebut. Namun, salah satu solusi yang dapat digunakan oleh guru menyikapi masalah tersebut adalah menggunakan web ataupun blog yang sudah berisi materi pembelajaran yang sesuai dengan tingkatan kelas. Hal ini sesuai dengan pendapat Khusniyah \& Hakim (2019) bahwa semakin banyaknya blog pendidikan yang dapat digunakan oleh guru untuk membantu terlaksananya proses pembelajaran daring. Selain solusi tersebut, tim PKM juga memberikan solusi lain, yakni pelatihan singkat menggunakan salah satu platform pembelajaran daring yang mudah digunakan, yakni Google Classroom. Kegiatan ini dilaksanakan pada kegiatan sosialisasi awal di fase tatap muka. Google Classroom merupakan salah satu Learning Management System (LMS) yang paling mudah untuk digunakan baik oleh guru maupun siswa, karena semua item aplikasi sudah ada pada Google Classroom, guru hanya menuliskan materi dan tugas apa yang akan diberikan kepada siswa. Berdasarkan hasil penelitian-penelitian sebelumnya, dijelaskan bahwa penggunakan Google Classroom sangat membantu para guru, khususnya guru yang masih belum terampil dalam menggunakan TIK pada proses pembelajaran (Ramadhani et al., 2019a, 2019b; Utami, 2019).

Tim PKM juga menuliskan buku referensi terkait penerapan pendidikan anti-hoaks serta pemahaman dasar mengenai studi politik. Buku referensi ditulis oleh seluruh tim PKM beserta mahasiswa-mahasiswa yang berasal dari program studi Hubungan Internasional, Universitas Potensi Utama. Buku referensi tersebut selanjutnya diberikan kepada seluruh guru untuk dijadikan referensi tambahan dalam memahami pendidikan anti-hoaks.

Selain memberikan buku referensi, Tim PKM juga memberikan modul penggunaan Google Classroom sebagai salah satu upaya untuk membantu para guru dalam 
menggunakan Google Classroom sebagai kelas digital selama pembelajaran daring di masa pandemi COVID-19.

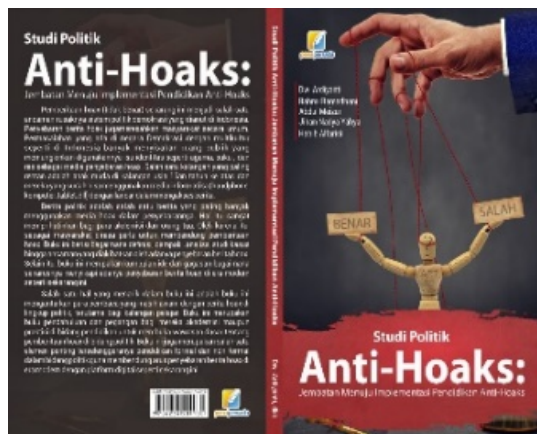

Gambar 1. Tampilan Referensi yang Telah Diterbitkan oleh Penerbit Pena Persada

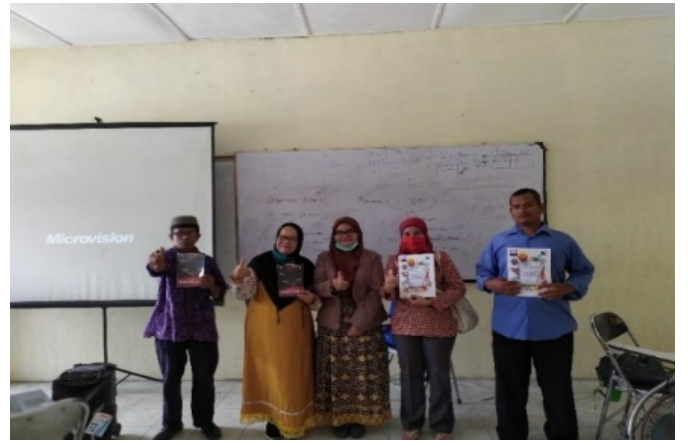

Gambar 2. Pemberian Buku Referensi dan Modul Penggunaan Google Classroom kepada Perwakilan Guru Sekolah Mitra

3. Selain buku referensi, Tim PKM juga mengembangkan aplikasi sistem penjaring informasi hoaks berbasis website untuk digunakan para guru dalam memilah informasi yang akan digunakan dalam pemberian materi ajar selama pembelajaran daring di masa pandemi COVID-19. Aplikasi tersebut dirancang dan didesain langsung oleh salah satu anggota tim PKM yang juga merupakan ahli IT di bidang sistem informasi. Berikut tampilan awal aplikasi sistem penjaring informasi hoaks berbasis website yang dikembangkan oleh Tim PKM:

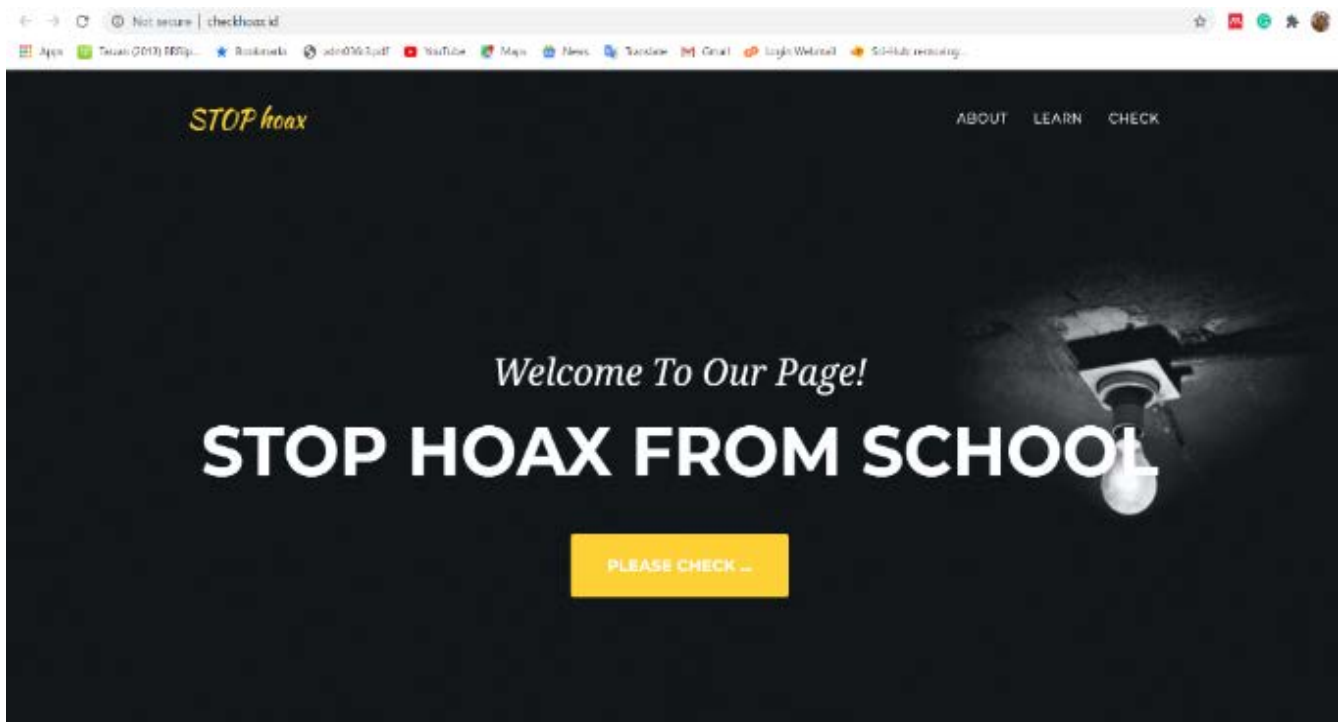

Gambar 3. Pemberian Buku Referensi dan Modul Penggunaan Google Classroom kepada Perwakilan Guru Sekolah Mitra

4. Aplikasi sistem penjaring informasi hoaks berbasis website yang telah dikembangkan selanjutnya disosialisasikan kepada para guru sekolah mitra terkait teknis penggunaannya. Hasil kegiatan sosialisasi ini dapat dilihat dari perhitungan angket pada grafik di bawah ini: 


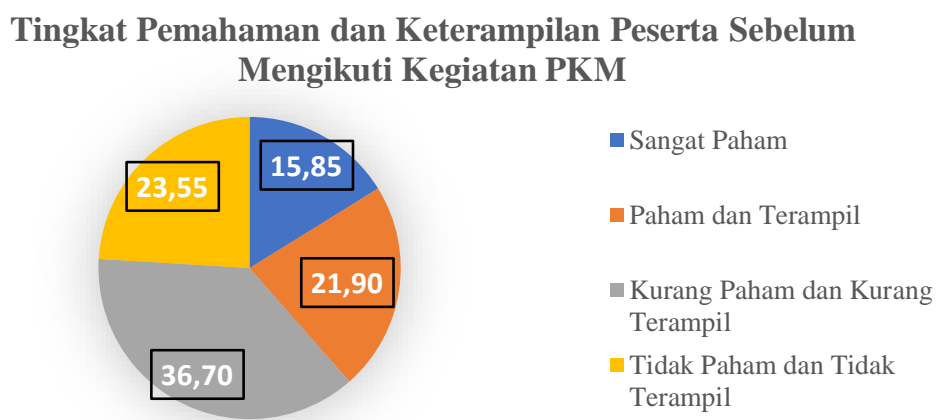

Gambar 4. Grafik Perhitungan Hasil Angket Sebelum Kegiatan PKM

Berdasarkan hasil perhitungan angket pada Gambar 4, diperoleh bahwa sebelum diberikan pelatihan dan pendampingan sebanyak 15,85\% peserta kegiatan menyatakan sangat mengetahui dan sangat terampil dalam menggunakan aplikasi yang dapat menjaring informasi hoaks yang sejenis dengan aplikasi yang dikembangkan oleh Tim PKM; 21,90\% peserta kegiatan menyatakan mengetahui dan terampil dalam menggunakan aplikasi yang dapat menjaring informasi hoaks yang sejenis dengan aplikasi yang dikembangkan oleh Tim PKM; 36,70\% peserta kegiatan menyatakan kurang mengetahui dan kurang terampil dalam menggunakan aplikasi yang dapat menjaring informasi hoaks yang sejenis dengan aplikasi yang dikembangkan oleh Tim PKM; dan 23,55\% peserta kegiatan menyatakan tidak mengetahui dan tidak terampil dalam menggunakan aplikasi yang dapat menjaring informasi hoaks yang sejenis dengan aplikasi yang dikembangkan oleh Tim PKM.

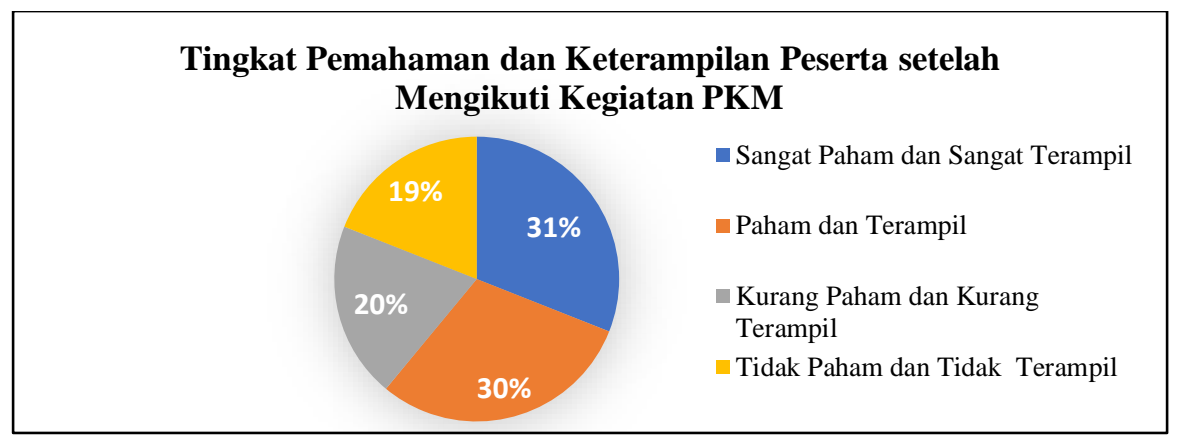

Gambar 5. Grafik Perhitungan Hasil Angket Setelah Kegiatan PKM

Sedangkan hasil perhitungan angket yang dapat dilihat pada Gambar 5, diperoleh bahwa setelah diberikan pelatihan sebanyak $31 \%$ peserta kegiatan menyatakan sangat mengetahui dan sangat terampil dalam menggunakan aplikasi yang dapat menjaring informasi hoaks berbasis website yang dikembangkan oleh Tim PKM; 30\% peserta kegiatan menyatakan mengetahui dan terampil dalam menggunakan aplikasi yang dapat menjaring informasi hoaks berbasis website yang dikembangkan oleh Tim PKM; 20\% peserta kegiatan menyatakan kurang mengetahui dan kurang terampil dalam menggunakan aplikasi yang dapat menjaring informasi hoaks berbasis website yang dikembangkan oleh Tim PKM; dan 19\% peserta kegiatan menyatakan tidak mengetahui dan tidak terampil dalam menggunakan aplikasi yang dapat menjaring informasi hoaks berbasis website yang dikembangkan oleh Tim PKM. Berdasarkan grafik perhitungan, 
maka diperoleh kesimpulan bahwa terdapat peningkatan pengetahuan dan keterampilan peserta kegiatan dalam menggunakan aplikasi yang dapat menjaring informasi hoaks berbasis website yang dikembangkan oleh Tim PKM. Tabel peningkatan pengetahuan dan keterampilan peserta dapat dilihat pada tabel 2.

Tabel 2. Hasil Peningkatan Persentasi Hasil Angket Kegiatan PKM

\begin{tabular}{|c|c|c|c|}
\hline \multirow[b]{2}{*}{ Indikator } & \multicolumn{2}{|c|}{ Pemberian Angket (\%) } & \multirow{2}{*}{$\begin{array}{c}\text { Persentase } \\
\text { Peningkatan/ } \\
\text { Penurunan }\end{array}$} \\
\hline & $\begin{array}{l}\text { Sebelum Pelatihan } \\
\text { dan Pendampingan }\end{array}$ & $\begin{array}{c}\text { Setelah Pelatihan } \\
\text { dan Pendampingan }\end{array}$ & \\
\hline $\begin{array}{l}\text { Sangat Paham dan } \\
\text { Sangat Terampil }\end{array}$ & $15,85 \%$ & $31 \%$ & $\begin{array}{l}\text { Meningkat } \\
48,87 \%\end{array}$ \\
\hline $\begin{array}{l}\text { Paham dan } \\
\text { Terampil }\end{array}$ & $21,90 \%$ & $30 \%$ & $\begin{array}{l}\text { Meningkat } \\
27 \%\end{array}$ \\
\hline $\begin{array}{l}\text { Kurang Paham dan } \\
\text { Kurang Terampil }\end{array}$ & $38,70 \%$ & $20 \%$ & $\begin{array}{l}\text { Menurun } \\
48,32 \%\end{array}$ \\
\hline $\begin{array}{l}\text { Tidak Paham dan } \\
\text { Tidak Terampil }\end{array}$ & $23.55 \%$ & $19 \%$ & $\begin{array}{c}\text { Menurun } \\
19,32 \%\end{array}$ \\
\hline
\end{tabular}

Berdasarkan tabel di atas, terlihat bahwa indikator (1) dan (2) mengalami peningkatan setelah diberikan pelatihan dan pendampingan dalam menggunakan aplikasi yang dapat menjaring informasi hoaks berbasis website yang dikembangkan oleh Tim PKM, yakni sebesar 75,87\%. Hasil tersebut menunjukkan bahwa peningkatan pengetahuan dan keterampilan peserta kegiatan setelah mengikuti rangkaian kegiatan PKM masuk dalam katagori “Baik”. Hal tersebut sesuai dengan tabel perhitungan angket di bawah ini:

Tabel 3. Kegiatan Perhitungan Angket (Arikunto, 2013)

\begin{tabular}{ccc}
\hline No & $\begin{array}{c}\text { Rentang Persentase Hasil } \\
\text { Angket }\end{array}$ & Katagori \\
\hline 1. & $80 \% \leq P \leq 100 \%$ & Sangat Baik \\
2. & $65 \% \leq P \leq 79,99 \%$ & Baik \\
3. & $55 \% \leq P \leq 64,99 \%$ & Cukup \\
4. & $40 \% \leq P \leq 54,99 \%$ & Kurang \\
5. & $0 \% \leq P \leq 39,99 \%$ & Sangat Kurang \\
\hline
\end{tabular}

5. Berdasarkan hasil perhitungan angket tersebut, maka dapat ditunjukkan bahwa kegiatan PKM yang telah dilaksanakan berhasil meningkatkan pengetahuan, keterampilan dan motiviasi para guru sekolah mitra dalam menggunakan sistem penjaring informasi hoaks berbasis website di masa pandemik COVID-19. Para guru juga dapat mengimplementasikan penelusuran informasi berbasis internet menggunakan informasi yang valid dan kredibel dalam proses pembelajaran daring di masa pandemik COVID19. Hasil yang diperoleh ini juga dijadikan sebagai jembatan untuk mengimplementasikan program pendidikan anti-hoaks di lembaga pendidikan.

6. Hambatan yang terjadi selama pelaksanaan kegiatan PKM adalah adanya pembatasan waktu pelaksanaan kegiatan tatap muka yang dilakukan di sekolah mitra sebagai langkah pencegahan penyebaran COVID-19. Selain itu, hambatan lainnya adalah pelaksanaan pendampingan secara daring yang belum optimal. Hal ini disebabkan masih ada 
beberapa guru mitra yang belum terbiasa menggunakan fasilitas Zoom Meeting, sehingga beberapa kali mengalami kendala dalam bergabung pada kegiatan pendampingan daring. Jaringan internet yang sering tidak stabil di beberapa daerah tempat tinggal guru mitra juga menjadi salah satu kendala dan hambatan yang dialami oleh Tim PKM.

\section{KESIMPULAN}

Tim PKM telah melaksanakan program pelatihan dan pendampingan penggunaan sistem penjaring informasi hoaks berbasis website dalam menerapkan pendidikan antihoaks di masa pandemi COVID-19 bagi guru sekolah mitra sesuai dengan tahapan yang telah direncanakan. Berdasarkan kegiatan tersebut, maka dapat disimpulkan bahwa kegiatan pelatihan dan pendampingan yang telah dilakukan mampu mendorong para guru sekolah mitra dalam meningkatkan pengetahuan menjaring informasi hoaks. Selain itu, para guru telah mampu meningkatkan keterampilannya dalam menggunakan aplikasi sistem penjaring informasi Hoaks berbasis website sebagai bagian dari referensi dalam mengembangkan bahan ajar digital.

Rekomendasi kegiatan PKM selanjutnya adalah penerapan pendidikan anti-hoaks bagi siswa, khususnya siswa SMA sederajat. Pendidikan anti-hoaks merupakan program pendidikan yang memberikan pengetahuan dan keterampilan kepada siswa SMA sederajat untuk lebih cerdas dan kritis dalam menanggapi informasi serta memilah informasi yang akan digunakan.

\section{UCAPAN TERIMA KASIH}

Ucapan terima kasih tim PKM sampaikan kepada Kementerian Riset dan Teknologi/Badan Riset dan Inovasi Nasional yang telah mendanai Kegiatan Program Kemitraan Masyarakat (PKM) ini melalui Skema Hibah Program Kemitraan Masyarakat (PKM) Pendanaan Tahun 2020.

\section{DAFTAR PUSTAKA}

Arikunto, S. (2013). Dasar-Dasar Evaluasi Pendidikan. Bumi Aksara.

Juditha, C. (2018). Interaksi Komunikasi Hoax di Media Sosial serta Antisipasinya Hoax Communication Interactivity in Social Media and Anticipation. Jurnal Pekommas, 3(1), 31-44.

Kementerian Pendidikan dan Kebudayaan. (2013). Kerangka Dasar dan Struktur Kurikulum 2013. Kemendikbud.

Khusniyah, N. L., \& Hakim, L. (2019). Efektifitas Pembelajaran Berbasis Daring: Sebuah Bukti pada Pembelajaran Bahasa Inggris. Jurnal Tatsqif, 17(1), 19-33. https://doi.org/10.20414/jtq.v17i1.667

Latip, A. (2020). Peran Literasi Teknologi Informasi dan Komunikasi pada Pembelajaran Jarak Jauh di Masa Pandemi COVID-19. EduTeach: Jurnal Edukasi Dan Teknologi Pembelajaran, 1(2), 107-115.

Nasution. (2010). Teknologi Pendidikan. Bumi Aksara.

Nugraha, M. T. (2019). Hoax di Media Sosial Facebook: Antara Edukasi dan Propaganda Kepentingan. Jurnal Sosiologi Walisongo, 3(1), 97-108. 
https://doi.org/10.21580/jsw.2019.3.1.3359

Pakpahan, R., \& Fitriani, Y. (2020). Analisa Pemanfaatan Teknologi Informasi dalam Pembelajaran Jarak Jauh di Tengah Pandemi Virus Corona COVID-19. Journal of Information System, Applied, Management, Accounting and Research, 4(2), 30-36. http://journal.stmikjayakarta.ac.id/index.php/jisamar/article/view/181

Pertiwi, W. K. (2019). Facebook Jadi Medsos Paling Digemari di Indonesia Halaman all Kompas.com. https://tekno.kompas.com/read/2019/02/05/11080097/facebook-jadimedsos-paling-digemari-di-indonesia?page $=$ all

Prawiyogi, A. G., Purwanugraha, A., Fakhry, G., \& Firmansyah, M. (2020). Efektivitas Pembelajaran Jarak Jauh terhadap Pembelajaran Siswa di SDIT Cendekia Purwakarta. Jurnal Pendidikan Dasar, 11(1), 94-101. https://doi.org/10.21009/10.21009/JPD.081

Ramadhani, R., Astuti, E., \& Setiawati, T. (2019a). Implementasi LKS Berbasis Budaya Lokal Menggunakan LMS Google Classroom di Era Revolusi Industri 4,0. SINDIMAS, 1(1), 13-17. https://doi.org/10.30700/SM.V1I1.527

Ramadhani, R., Astuti, E., \& Setiawati, T. (2019b). The Implementation of LMS-Google Classroom to Improving Competence Skill of Senior High School Teachers' in Industrial Revolution 4.0. AMALIAH: JURNAL PENGABDIAN KEPADA MASYARAKAT, 3(2), 327-335. https://doi.org/10.32696/ajpkm.v3i2.286

Sadikin, A., \& Hamidah, A. (2020). Pembelajaran Daring di Tengah Wabah COVID-19. BIODIK: Jurnal Ilmiah Pendidikan Biologi, 6(2), 214-224. https://doi.org/10.22437/bio.v6i2.9759

Sartono. (2016). Pemanfaatan Blog Sebagai Media Pembelajaran Alternatif di Sekolah. Transformatika, 12(1), 120-134.

Soewarno, Hasmiana, \& Faiza. (2016). Kendala-Kendala yang Dihadapi Guru dalam Memanfaatkan Media Berbasis Komputer di SD Negeri 10 Banda Aceh. Jurnal Pesona Dasar, 2(4), 28-39.

Sulasmianti, N. S. (2019). Pemanfaatan Blog sebagai Media Pembelajaran. Jurnal Teknodik, O(0), 143. https://doi.org/10.32550/teknodik.v0i0.365

Utami, R. (2019). Analisis Respon Mahasiswa terhadap Penggunaan Google Classroom pada Mata Kuliah Psikologi Pembelajaran Matematika. PRISMA: Prosiding Seminar Nasional Matematika, 498-502. https://journal.unnes.ac.id/sju/index.php/prisma/article/view/29040 